\title{
A MUNICIPAL SCHEME FOR DEALING WITH CONSUMPTION.
}

\author{
By H. SCURFIELD, M.D., D.P.H. \\ (MEMBER.)
}

\begin{abstract}
THE Local Government Board of Scotland has recently propounded 1 by means of a circular and the re-issue of a paper by Dr. Philip, of Edinburgh, a complete scheme for dealing with tuberculosis of the lungs.

It may not be uninteresting to point out how the Sheffield scheme for dealing with this disease is developing, and to what extent it approximates to Dr. Philip's ideal.
\end{abstract}

Dr. Philip asks for-

1. A Tubercolosis Dispensary.

2. A Sanatorium.

3. A Hospital for Advanced cases.

4. An After-life Colony.

We have not advanced far towards the goal at present. We have :-

1. Compulsory notification, and a scheme approved to use some of the wards of the Isolation Hospitals for educative treatment and the selection of cases for Sanatorium treatment.

2. A Committee appointed for the purpose of establishing a Sanatorium. Some accommodation for open-air treatment provided by both Boards of Guardians.

3. Accommodation for advanced cases proviled in separate wards by the Boards of Guardians.

Reverting to Dr. Philip's scheme, I think it will be found that when compulsory notification has been adopted there is no need to establish a Tuberculosis Dispensary.

When we have the use of the Isolation Hospital warls and a Sanatorium the routine will be something as follows :-

1. Aid to early diagnosis. - A medical man has a suspicious case. He sends the sputum to the Bacteriological Laboratury of the University, where it is examined free of charge, by arrangement with the Corporation. 


\section{A Municipal Scheme for Dealing wiilh Consumption.}

2. Totification.-If the result of the examination is positive, the case is notified. If the medical man does not wish the case visited by the Tuberculosis Inspector he states so at the time of notificntion and fills in a special form stating that precautions are being taken to prevent the spread of infection. The form is filled in again every six months during the progress of the case. This procedure is only adopted in from one to two per cent. of the cases notified in Sheffield.

The Compulsory Notification $A$ ct has been in force since November 1st, 1903 , and there has been no opposition on the part of the public or of the medical practitioners. I have no doubt there has been some little failure to notify on the part of the medical practitioners. This, however, is only what one would expect with a new let.

The following is a statement of the number of deaths from consumption in the City of Sheffield :-

\section{Period.}

Nov. 1st, 1903, to A pril 30th, 1904

May 1st, 1904, to Oct. 31st, 1904

Nor. 1st, 1904, to April 30th, 190J

May 1st, 1905, to Oct. 31st, 1905
Number of Denths
from 'Tuberculosis of the lungs,

315

$2+1$

272

232
Number of persons who have Died from T'uberculosis of the Jungs willout being notiliet.

3. The following table shows the deaths from tuberculosis of the lungs and the cases notified in the years given. Voluntary notification begall in the last month of 1899 , and compulsory on Norember 1st, 1903 :-

$\begin{array}{llllllll} & 1899 . & 1900 . & 1901 . & 1902 . & 1903 . & 1904 . & 1900 . \\ \text { Cases notified } & 29(1 \text { month }) & 309 & 282 & 326 & 519 & 826 & 741 \\ \text { Deaths } & 502 & 539 & 580 & 491 & 573 & 536 & 490()\end{array}$

After notification has been in force for a few years, the difference between the cases notificd and the cleaths will not be so great. The difference between the two figures will be determined by the numbar who recorer or die elsewhere, or who are certified as dying from some oflere cause.

The number of notified consumptives who are certified as dying from some other cause is considerable. Thus in 1904 twenty-five, and in 1905 twenty-seren notified consumptives were certified as dying from some other cause. In the case of thirteen and nine respectively of these the death was classified as from tuberculosis of the lungs, after consultation with the medical man who signed the certificate.

The period of the disease at which notification will occur will no doubt vary with the circumstances of the patient. Among the well-to-do one 
expects early notification. Among the poorer classes the doctor will of ten not be consulted till the disease is fairly advanced.

The Act lias not been in force long cnough in Sheffield to enable me to say what period will on the average elapse between notification and death. When it first came into force a large number of cases which were very advanced would be notified.

I find that of the cases notificd in the sccond half of 1904 , that is, after the Act had been in operation for eight months, there were

$\begin{array}{crrrrrr}\text { Surviving } & 3 & \text { month after notification } & \ldots & 62 \cdot 2 & \text { per cent. } \\ " & 6 & " & " & \ldots & 52 \cdot 3 & " \\ " & 9 & " & " & \ldots & 45 \cdot 0 & " \\ " & 12 & , & " & \ldots & 39 \cdot 6 & " \\ " & 15 & , & " & \ldots & 35 \cdot 6 & " \\ " & 18 & " & " & \ldots & 33 \cdot 5 & "\end{array}$

3. Supercision, $\& \cdot c .-$ On reccipt of the notification a special Inspector visits. He leares a copy of instructions with the patient or the relatives. He advises as to keeping the winlows open and furnishes the poorer of the patients with pocket spittoons free of charge. The spittoons cost 57s. per gross. The Inspector, on his first visit, gets all particulars and the history of the case and pays subsequent visits at regular intervals. In cases where the house is dirty or the patient much confined to the house by his illness the room is disinfected with formalin spray by the Inspector at the time of his risit. The room is also disinfected after deatl. The houseloolder is asked to notify the death on its occurrence, and in very many cases this reyuest is observed.

If the consumptive is still at work, enquiries are made as to his place of work, with a view to the removal of any causes which may have helped the development of the disease, or to the protection of co-workers from the risk of infection. The fact of workmen at factories having developed consumption is also reported to II.M. Inspector of Factories, so that he may make enquiries as to the efficiency of ventilation, the means adopted for the removal of dust, \&c.

4. Hospital and Sanatorium Treatment.-When the infectious riseases' hospital wards are available for the reception of the patients, the inspectors will urge the cases notified to take advantage of them according to their circumstances. The idea is to take them for a montl, as is clone at Brighton, for the purpose of educating them and giving their relatives a rest, and also for the purpose of selecting those who are suitable subjects for sanatorium treatment.

An effort will be made to induce the bally-housed actranced cases at 
the end of the month to go into the special wards provided by the guardians.

5. Hospitals for Advanced Cases.-There is no doubt that the special wards of the Union hospitals are at present accommodating a large number of the worst-housed cases, and to some extent supplying the need for homes for advanced cases. This has been suggested by Dr. Newsholme as one of the important factors in the decline of the death-rate from consumption.

The following table shows the percentage of the consumption deaths occurring in the Sheffield Workhouse Hospitals and the Sheffield consumption death-rate side by side since 1874 :-

Table A.-Phthisis Mortality in City and Workhouse Hospitals.

\begin{tabular}{|c|c|c|c|c|}
\hline Year. & $\begin{array}{l}\text { Number of Deaths } \\
\text { from Consumption } \\
\text { in Workhouse } \\
\text { Hospitals. }\end{array}$ & $\begin{array}{l}\text { Number of Deaths } \\
\text { from Consumption } \\
\text { in the City. }\end{array}$ & $\begin{array}{c}\text { Percentage } \\
\text { occurring in } \\
\text { Workhouse } \\
\text { Hospitals. }\end{array}$ & $\begin{array}{l}\text { Death.rate } \\
\text { per 160,000 from } \\
\text { Consunption ia } \\
\text { Shemeld. }\end{array}$ \\
\hline $\begin{array}{l}1874 \\
1875 \\
1876 \\
1877 \\
1878 \\
1879 \\
1880 \\
1881 \\
1882 \\
1883 \\
1884 \\
1885 \\
1886 \\
1887 \\
1888 \\
1889 \\
1890 \\
1891 \\
1892 \\
1893 \\
1894 \\
1895 \\
1896 \\
1897 \\
1898 \\
1899 \\
1900 \\
1901 \\
1902 \\
1903 \\
1904 \\
1905\end{array}$ & $\begin{array}{c}25 \\
32 \\
42 \\
38 \\
39 \\
35 \\
35 \\
41 \\
40 \\
39 \\
\text { No record. } \\
54 \\
38 \\
54 \\
\text { No record. } \\
62 \\
75 \\
81 \\
59 \\
74 \\
72 \\
76 \\
56 \\
90 \\
98 \\
117 \\
135 \\
142 \\
121 \\
142 \\
154 \\
133\end{array}$ & $\begin{array}{c}\text { No record. } \\
\text { No record. } \\
638 \\
658 \\
644 \\
644 \\
601 \\
476 \\
480 \\
551 \\
635 \\
\text { No record. } \\
560 \\
494 \\
534 \\
527 \\
552 \\
618 \\
551 \\
459 \\
552 \\
502 \\
473 \\
453 \\
522 \\
448 \\
502 \\
539 \\
580 \\
491 \\
560 \\
536 \\
486\end{array}$ & $\begin{array}{c}\text { No record. } \\
\text { No record. } \\
6 \cdot 6 \\
5 \cdot 8 \\
6 \cdot 1 \\
5 \cdot 8 \\
7 \cdot 4 \\
8 \cdot 5 \\
7 \cdot 3 \\
6 \cdot 1 \\
\text { No record. } \\
9 \cdot 6 \\
7 \cdot 7 \\
10 \cdot 1 \\
\text { No } 1 \cdot \text { eenrd. } \\
11 \cdot 2 \\
12 \cdot 1 \\
14 \cdot 7 \\
12 \cdot 9 \\
13 \cdot 4 \\
14 \cdot 3 \\
16 \cdot 1 \\
12 \cdot 4 \\
17 \cdot 2 \\
21 \cdot 9 \\
23 \cdot 4 \\
25 \cdot 0 \\
24 \cdot 5 \\
24 \cdot 6 \\
25 \cdot 4 \\
28 \cdot 7 \\
27 \cdot 4\end{array}$ & $\begin{array}{c}\text { No record. } \\
\text { No record. } \\
243 \\
247 \\
238 \\
218 \\
170 \\
168 \\
191 \\
217 \\
\text { No record. } \\
183 \\
158 \\
168 \\
163 \\
168 \\
192 \\
169 \\
139 \\
165 \\
147 \\
136 \\
128 \\
146 \\
123 \\
136 \\
143 \\
141 \\
117 \\
134 \\
124 \\
110\end{array}$ \\
\hline
\end{tabular}

The average period of residence of cases of consumption at Firvale Workhouse Hospital has recently been 311 days.

I hope we shall soon have our consumption wards in the Isolation 
Hospitals and our Sanatorium in use, and then I consider the scheme will be fairly complete.

6. After-life Colony.-The after-life colony is even more in the future. The difficulties do not seem very great. One colony under separate management might serve for several sanatoria. Supposing the cost were $\mathfrak{f 1}$ per week, the work of the ex-patient would probably be worth 10s. a week on his first arrival, and the local authority might pay a gradually-diminishing charge per week till the ex-patient was able to work for his keep.

Cotnciulon Bonser (Southampton) agreed with the idea that the principle of compulsory notification for phthisis should not be adopted without a guarantee of the simultaneous provision of adequate inspection, education, and, if necessary, sanatorium accommodation.

Miss Josepir (London, Jewish Bonrd of Guardians) said that "where ignorance was bliss, 'twas folly to be wise." Compulsory notification of consumption must bring with it knowledge of the clisease, and at least it should be followed by systenatic inspection. Perhaps notbing in this connection made one feel more uncomfortable than the knowledge of how phthisis was spread, and how very little was done at present to prevent it.

Dr. A. K. Chalderers (Glasgow) said that the diverse opinions expressed by previous spealers served to emphasize the interest which all felt in the administrative treatment of consumption. Arguments for and against its compulsory notification seemed to find their focus in one paragraph of Dr. Scurfield's paper, where he said that notification would probably do away with the need for establishing dispensaries. There was no question as to the desirability of a local authority knowing where the disease existed. The only question was how best this was to be obtained.

Dr. H. Scurfield (Sheffield), in replying, said that he beliered in doing something for consumption in all stages. His own experience of fever hospitals and of the Durham Sanatorium had shown him that the cost of a consumptive in a sanatorium was about 2s. 6d. per week mure than the cost of a patient in a fever hospital. In sheffield there were about 1,000 consumptives, and if 40 beds in the ferer hospital on the Brighton system and 20 beds in a sanatorium were put at the disposal of consumptives, this, together with the accommodation at present provided by the Guardians, would go a long way towards providing the hospital treatment suitable for ench stage of the disease. One of the adrantages of compulsory notification was that it enabled one to educate the consumptive directly, which was much more effectual than attempting to educate the whole community in anti-consumption precautions. 